\title{
Are you a dissident? Art and diplomacy - two encounters
}

\section{GREGORY O'BRIEN}

Although his background was in science, the ambassador reminded me that, because he was a Russian, art and poetry were deeply, deeply rooted in his psyche. It followed that he knew well the Moscow writers' centre, the Gorkiy Institute, which I had visited with the poets Ian Wedde and Tusiata Avia a few months earlier. (We had stood in the room where Mayakovsky made his last public address, and beside the desk where he wrote some of his greatest verse...) Not far from Red Square, the Gorkiy Institute is a part of the Russian soul, he said, just as literature and art are. A Russian can never be a stranger to poetry.

It was while co-editing a special 'Russian' issue of the periodical Landfall (which appeared in May 2007), that I drank numerous cups of tea with Ambassador Mikhail Lysenko, usually with his attache Illya Pimenov in attendance. We first met at the City Gallery Wellington, where I worked, then later at the Residence in Karori. The proposed 'Russian' Landfall would be an appropriate act of cultural reciprocity to follow on from an anthology of New Zealand poetry translated into Russian, Land of Seas, the launch of which I had attended at the New Zealand Embassy in Moscow in June 2005. ${ }^{1}$

Soon after returning from that lively and memorable encounter with a city and its poets, I helped organise the Wellington launching of Land of Seas at the National Library. The antipodean celebration turned out to be a grand occasion, with many poets reading, among them Bill Manhire, J. C. Sturm and Roma Potiki; some Tchaikovsky was hammered out on the Library's grand piano, shot glasses of vodka circulated freely and there was much good talk and a little plotting of future projects.

Not long after that, an editorial team of Ian Wedde, Evgeny Pavlov, Jacob Edmond and myself was convened and we set to gathering material for our nascent Landfall. The contents would include contemporary Russian poems translated into English by local poets including Cilla McQueen, Chris Price and Vincent O'Sullivan (working from literal versions). We also commissioned or solicited essays, poetry, fiction, photographs of Russian poets (and one of tennis up-and-comer Maria Sharapova!) and some visual art by the Blue Noses, 'an art collective who invented themselves while on a "creative retreat" in a Siberian bomb shelter in $1999^{\prime} .^{2}$ It was on account of the latter contribution that a more serious tone entered my teadrinking sessions with Mr Lysenko.

As the Landfall was reaching its final form, the ambassador was given a mock-up of the issue so that he could survey the contents. Only after a thorough check might the journal bear the crest of the Russian Embassy upon its imprint page. Two days after couriering the contents up to him, I was summoned to the Ambassador's residence. I was surprised, upon arrival, to find Mr Lysenko in a state of some agitation.

He sat me down, tea was served, and he offered his account of the contents of the journal, much of which he felt unmoved by, but which he accepted on account of the credentials of the contributors. (He had clearly done background checks on Arcadii Dragomoshchenko and co.) He dwelt a while upon Amelia Harris's 'Notes on Other Passengers', wondering why the writer had concentrated so exhaustively on the decrepit inhabitants of a Russian railcar when she could have been looking out the window at the powerful, poetic Russian landscape. 
His mild disappointment was replaced by a graver tone when we came to the art collective, The Blue Noses - a selection of whose work had been compiled for the issue by Marcus Williams, a curator and teacher based at Unitec, Auckland. The proposed images included photographs of the three collective members stripped down to their underwear, standing in front of St Basil's Cathedral and other places 'sacred' to the Russian people. In one photograph, entitled Reality show, a member of the collective is having sex with a naked woman in what appears to be a prison cell; off to one side, a Lenin look-alike is 'turning in his grave'. There were jokes about Russian Suprematism, rebranded as Sex-Suprematism, incorporating computer-generated genitalia. But the real trouble started when we came to the images which incorporated the President of Russia, Vladimir Putin. Onto photographs of their own near-naked selves, the Blue Noses had collaged the faces of Putin, George W. Bush and Osama Bin Laden. Lumped together on an unmade bed, the three leaders were portrayed in various states of sexual connection and confusion, hugging and (in one image, which didn't appear in the published Landfall) having intercourse.

No matter what one thought of President Putin, My Lysenko stated, he was the leader of the Russian people and, accordingly, entitled to some respect. How could Mr Lysenko, as Ambassador, sanction this kind of craziness, this offensive idiocy? How could this be art? We decided to let matters rest for the time being and I arranged to return to the Residence at a later date, accompanied by the three other Landfall editors, so we could talk the issue out.

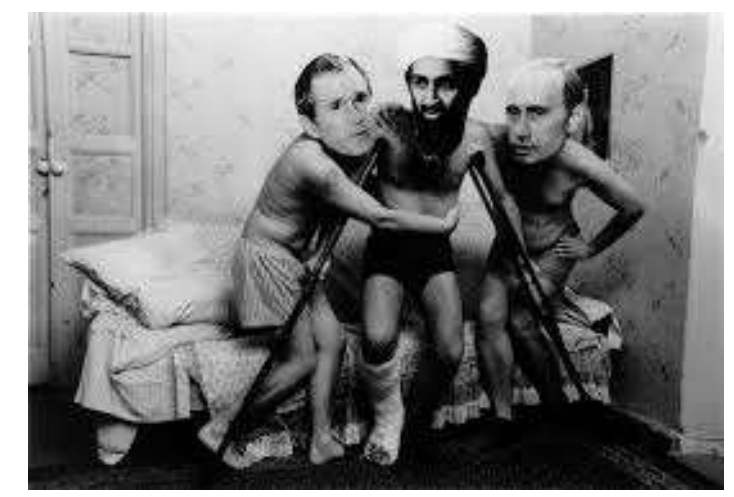

The Blue Noses, The Contemporary Siberian Artist \#2, silver gelatin print, 2001 (from a suite of works reproduced in Landfall 213)

Upon arrival at the Residence two weeks later, the atmosphere was strained. A lengthy, but reasonable, discussion ensued, during which Ian Wedde spoke compellingly about the Blue Noses and their international status. (He had seen their work first-hand at the 2005 Venice Biennale - where it had been 'a sensation'.) For the Landfall, Marcus Williams had already produced a strong, intelligent piece in defence of the Blue Noses - this we had earlier passed along to the ambassador-placing their agit-art firmly in the age-old Russian tradition of the 'Holy Fool', the yurodivy. (Interestingly, in 2013, following the arrest of the group Pussy Riot during an impromptu performance of 'Mother of God, chase Putin Out!' at the Moscow's Cathedral of Christ the Saviour, the punk girl bands' defence counsel argued along identical lines: that they were part of this central 'yurodivy' strand of Russian culture.) $)^{3}$ The Russian Ambassador was unswayed by this argument. It didn't change the nature of the insult, in his mind. While not for a moment respecting the art under discussion, he said he did, however, respect our position, and he acknowledged again that artistic expression was close to the heart of the Russian nation. 
There was a depressed feeling amongst the editors as we drove back across Wellington. Some days later, Mr Lysenko decided that - after much consideration - the Embassy of the Russian Federation could not place its crest on the issue. They could not officially 'sponsor' the publication, but that did not mean they would have no part of it. He acknowledged the seriousness which we, the editors, had brought to the project.

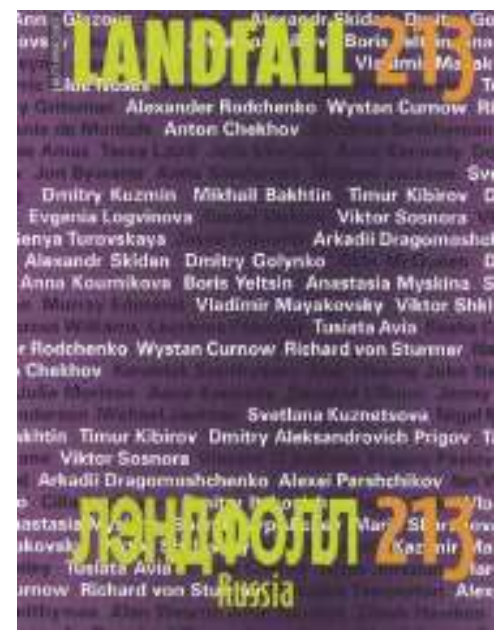

Landfall 213, May 2007, ed. Jacob Edmond, Gregory O'Brien, Evgeny Pavlov, Ian Wedde, Otago University Press

When Landfall 213, the Russian issue, was launched at the Christchurch Arts Centre in March 2007, Mr Lysenko, accompanied by his wife flew down for the event. They were more reserved than they had been when we celebrated the Russian/New Zealand anthology 18 months earlier, but some of the warmth remained. At an opportune moment, Mr Lysenko presented a bottle of vodka, a tray of glasses appeared from nowhere, and we all toasted cultural friendship between Russia and New Zealand. He reiterated, once again, that artistic expression was close to the heart of the Russian people. Then the Russians caught the late flight back up to Wellington. ${ }^{4}$

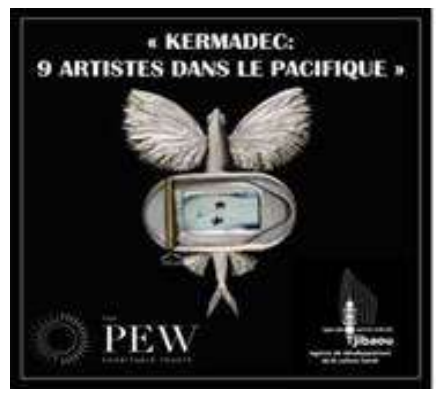

Visitez l'exposition

"Kermadec: 9 artistes dans le Pacifique »

en ce moment

au centre culturel Tjibaou!

In February this year I was reminded of this 'Russian experience', and the at times vexed relationship between art and politics, when I travelled to New Caledonia for the opening of the 'Kermadec' art exhibition at the Tjibaou Cultural Centre. It was four years since I had been part of an artists' expedition to Raoul Island on HMNZS Otago. In the intervening years, the 
exhibition of works inspired by the voyage - which was sponsored by the Washington-based Pew Charitable Trusts, as part of their Global Ocean Legacy programme - had travelled through New Zealand and as far afield as Chile. Pew's intention was to raise awareness of the pristine waters of the Kermadec region, in the hope that the New Zealand government would seriously consider designating the 620,000 square kilometre area a marine sanctuary. There was a good amount of support for the sanctuary proposal in official quarters. In fact, the National MP, Simon Bridges had launched the inaugural 'Kermadec' exhibition at Tauranga Art Gallery in November 2011 and then-Minister of Arts Chris Finlayson had helped launch the accompanying book at Unity Books, Culture and Heritage Wellington, around the same time.

From its point of origin north of the mainland, the Kermadec project had continued to expand into a many-tiered meditation upon - and a statement on behalf of - the health of the world's oceans. There were works in the Noumea exhibition which referred specifically to New Caledonia, Tonga and Rapanui/Easter Island as well as to the Kermadecs, and the ocean that bridges these places.

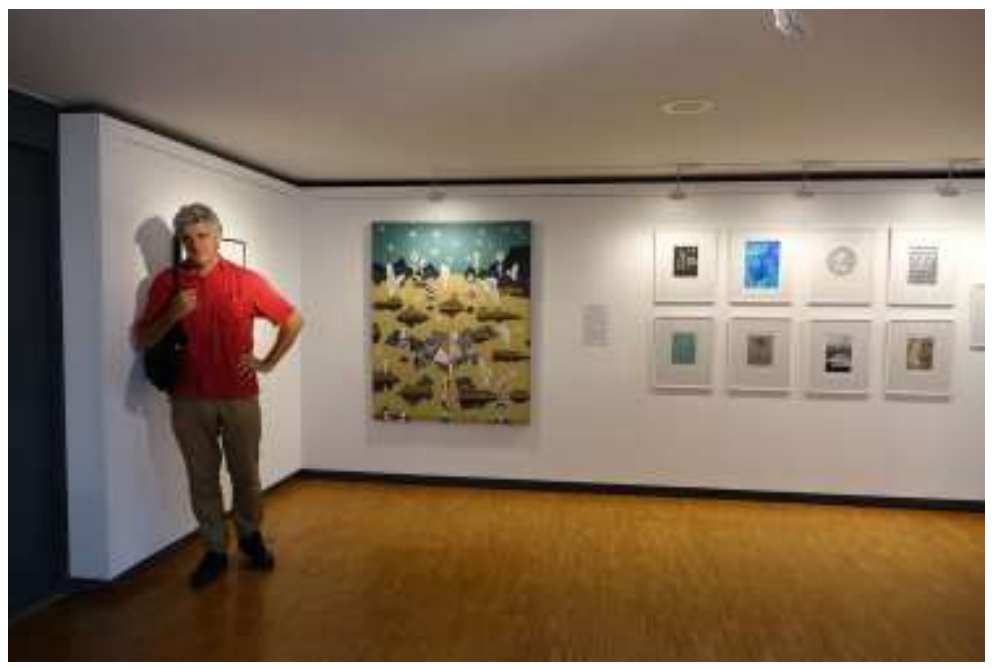

Gregory O'Brien--photographed by Elizabeth Thomson at the Tjibaou Cultural Centre, Noumea, in March 2015-alongside his La Cathedrale Engloutie / Raoul Island Whale Survey (a painting inspired by Wellington's Futuna Chapel as well as Debussy) and a suite of etchings made by the Kermadec artists in 2011.

By all accounts, the project proved an extraordinary vehicle for engendering discussion at many levels of society about one of the great, pressing topics of our time: the marine environment. Putting aside its theme for a moment, the project generated some remarkable and now wellknown works of art. As I wrote in a recent piece in $P N$ Review (UK):

Work produced as a result of the 2011 voyage continues to make its way far and wide. Kermadec-inspired works by Adelaide-based Fiona Hall will be featured in her exhibition in the Australian Pavilion at this year's Venice Biennale, at which Phil Dadson is also a featured artist; Thomson's wall-works have been shown in Berlin and Sydney; John Pule's What I will see there (2012) is now in the National Gallery of Australia collection and is on long-term display (Level II, International Art). Robin White's three vast Kermadec tapa-clothes, with a combined measurement of 75 square metres, will feature in her major solo exhibition at the National Gallery of Victoria in Melbourne next year. Four years after the voyage, there is as much activity as there ever was. ${ }^{5}$ 
That list represents only the tip of the artistic iceberg. One thing that continues to amaze me about the body of 'Kermadec' art, as a whole, is its pervasive sense of wonder and embrace. The exhibition is that very rare thing in the world of serious contemporary art: a celebration.

The Noumea exhibition, 'Kermadec; 9 artistes dans le pacifique sud', is believed to be the biggest presentation of contemporary New Zealand art to have yet reached the French Pacific. The Tjibaou is not only the most prestigious public gallery in the greater Pacific region, it is a focal point for multicultural life in New Caledonia. Accordingly, you would think the 'Kermadec' opening would be a big day in the calendar of the New Zealand Consul-General in Noumea.

A few days prior to the opening, I flew north with artists Dame Robin White and Elizabeth Thomson, and the exhibition curator Reuben Friend (who has, since this project, gone on to become director of Porirua's Pataka Art Museum). ${ }^{6}$ By the time we touched down, however, the project appeared to have been blacklisted, presumably by the Ministry of Foreign Affairs, on account of its conservationist/environmental inspiration. A few weeks earlier, a directive had been sent from Wellington to the New Zealand Consul-General in Noumea instructing staff 'not to support' the exhibition. It was later stated, not very convincingly, that this meant they were not to contribute any funds to the project. Presumably that meant staff could attend the exhibition opening and related events if they wanted to. Yet no one attended any of the formalities - with the exception of one member of office-staff who came along on our last night in Noumea. No formal or informal overtures were made to any of the visiting party; no acknowledgement or hospitality were offered.

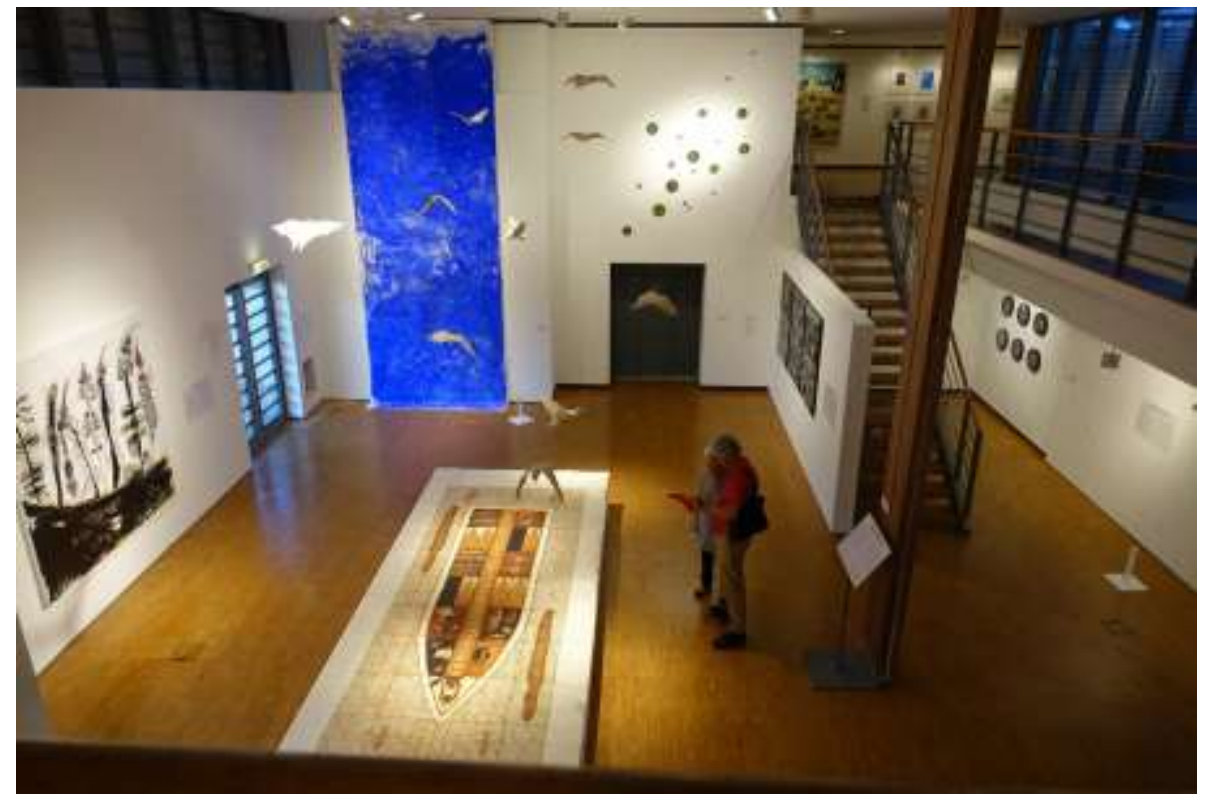

'Kermadec' exhibition at Tjibaou Cultural Centre, March 2103--works (from left) by John Pule, Robin White, John Reynolds, Elizabeth Thomson, Gregory O'Brien, Jason O'Hara

Before, as well as during, its four month run, 'Kermadec' would have been hard to miss. It was the subject of billboards, newspaper articles, television and radio programmes; it headlined the Tjibaou Centre's 2015 programme and was featured at the institution's annual open day (an event which, one imagines, New Zealanders in Noumea would surely make a point of attending). Whether the Consulate-General cares or not, the exhibition was a great success, with 33,000 visitors. $^{7}$ The works sang their oceanic song; future artistic collaborations with the 
Tjibaou are in discussion; and this latest chapter in the collective Pacific voyage that is the 'Kermadec' project has since given rise to new works, new poems and writings. The exhibition should have been a great opportunity for New Zealand to engage culturally with New Caledonia - the foreign nation closest to New Zealand's shores, closer even than Australia (a fact seldom made much of). We were told time and time again in Noumea that we should make more of the connection between our two countries.

Which brings me back to my conversations with Ambassador Lysenko and the comparatively dignified, intelligent and diplomatic way he dealt with the Blue Noses/Landfall conundrum. In the interests of freedom of speech, artistic freedom and cultural values, he was prepared to accommodate work that was subversive, politically driven and, indeed, hurtful. He certainly never personally or professionally condoned the work of the Blue Noses - and he carefully adjusted his position accordingly - but he could see it in the context of a broader matrix of cultural relations.

The official handling of the comparatively meek 'Kermadec' exhibition in Noumea was unintelligent, tawdry, mean-spirited and counter-productive. Every day we spent in at the Tjibaou someone would come up and ask us: Where on earth is the New Zealand Consulate? Why would a country disown a project that speaks so warmly and intimately of the environment and spirit of Aotearoa/New Zealand? What is it we could have done or said that has made dissidents of us?

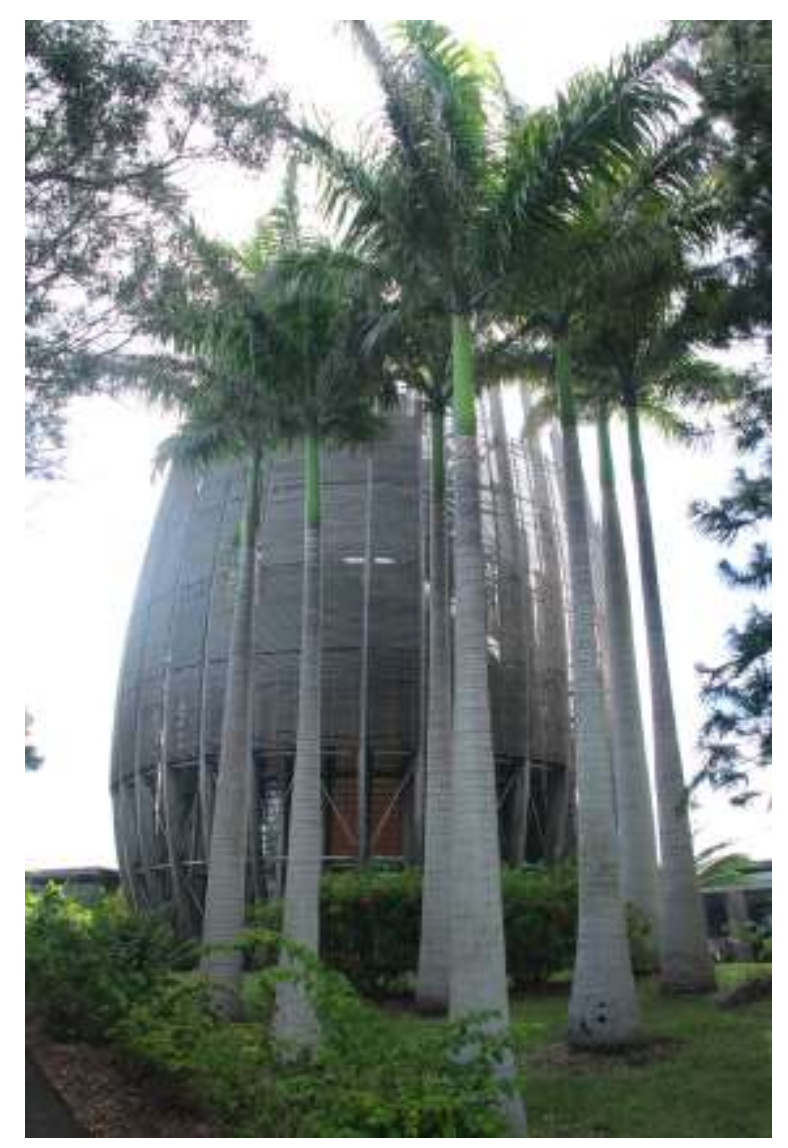

Renzo Piano-designed Tjibaou Cultural Centre, Noumea, photo by Elizabeth Thomson 


\section{September 2015 (one week later) - a coda}

Hardly three months after the 'Kermadec' exhibition was taken down in Noumea, Prime Minister John Key today announced, at the United Nations General Assembly in New York, the intention of the New Zealand Government to declare a 620,000 square kilometre marine sanctuary in the Kermadec region. The issue which had presumably rendered the exhibition untouchable in New Caledonia had now become official policy, and our politicians, beaming with what looked like a newly-awakened environmental fervor, were making the most of this opportunity to breast-stroke, somersault and glide in the untroubled, temperate waters of international approval. While the declaration itself is grounds for celebration, the cold shoulder given to the 'Kermadec' exhibition in Noumea raises a few questions about the logic and coherence of Governmental thinking and strategy, amongst other things.

\footnotetext{
${ }^{1}$ I acknowledge the generosity and enthusiasm of then-ambassador to Russia, Stuart Prior.

${ }^{2}$ Quotation here is taken from the contributor's notes, Landfall 213, p212

${ }^{3}$ Two years later, Williams co-curated and exhibition of six Russian artists, 'I am Russia', for the Dunedin Public Art Gallery. On that occasion, he told a newspaper interviewer that the Blue Noses (who featured in the show) were playing with 'stereotypes of Russia, like the exporting of sex-trade workers. They deliberately exploit their own grand history... Their work is based on the tradition of the "skomorokh" in the tsarist court, who were like European jesters.'

${ }^{4}$ Although the Russian Embassy's crest was not on the imprint page, the editors of Landfall included the following grateful acknowledgement to 'the Embassy of the Russian Federation in Wellington and Ambassador Mikhail Lysenko, without whose encouragement this would not have eventuated'. The introduction also noted, apropos the Blue Noses: 'Reflecting this combination of the deeply serious and the seriously playful, Landfall 213 celebrates the gains in civic and cultural freedoms hard-won by the peoples of Russia and the assertion of these freedoms in the imaginative work of Russian artists and writers.

${ }^{5}$ Gregory O'Brien, 'In defence of poetry as an offshore island and art as an undersea mammal or coral reef', PNReview 42:2, November-December 2015, Issue 226, p25.

${ }^{6}$ It is worth noting that none of the artists were receiving any recompense for their time or the presentation of their work. (Paradoxically, given the diplomatic cold shoulder, travel and other expenses for the project were assisted by Creative New Zealand.)

${ }^{7}$ After an inordinate amount of prompting, the Consul-General did in fact visit the exhibition a week before it closed.
} 